\title{
Emozio positiboak: alde argiak eta alde ilunak
}

\author{
Pello HuizI
}

ILCLIko ikertzaile ohia

\section{(Positive emotions: light sides and dark sides)}

DOI: $10.1387 /$ gogoa.20362

\begin{abstract}
The aim of this paper is to study the light sides and the dark sides of positive emotions. To this aim, I first present the differences between positive and negative emotions, as well as the history of the research on positive emotions in the history of psychology. With regard to the light sides of positive emotions, I consider three fields widely studied by the researchers: the relationship between positive emotion and health (and longevity), the relationship between positive emotion and cognition, and the relationship between positive emotion and interpersonal relationships. In relation to the dark sides of positive emotions, I report the negative outcomes found by the researchers in some of the positive emotions, those that have been subject of extensive research. I finish summarizing the six key themes proposed by Gruber and Purcell (2015) in order to encompass the ways positive emotions may go awry.
\end{abstract}

Keywords: positive emotion, valence, positive psychology, broaden-and-build theory, positive emotion light sides, positive emotion dark sides.

\section{Laburpena}

Emozio positiboen alde argi eta alde ilunak aztertzea da lan honen helburua. Hori dela eta, aurrena emozio positiboen eta emozio negatiboen arteko ezberdintasunak aurkezten ditut, baita emozio positiboei buruzko ikerketari eskaini izan zaion lekua ere psikologiaren historian. Emozio positiboen eta negatiboen arteko aldeak direla eta, «balentzia» kontzeptuaren garrantziaz eta esanahiaz hitz egiten dut. Emozio positiboen alde argiei dagokienez, ikertzaileek arreta handiz aztertutako hiru arlo hartzen ditut kontuan: emozio positiboen eta osa- 
sunaren (eta longebitatearen) arteko lotura, emozio positiboaren eta kognizioaren artekoa eta emozio positiboaren eta pertsona arteko harremanen arteko lotura. Emozio positiboen alde ilunei dagokienez, ikertzaileek aurkitu dituzten emozio positibo batzuen, gehien aztertu direnen, ondorio negatiboen berri ematen dut. Gruber eta Purcellek (2015), emozio positiboek izan ditzaketen emaitza txar motak laburbildu nahian, proposatzen dituzten sei sail edo multzo nagusien aurkezpen laburra eginez bukatzen dut artikulua.

Gako-hitzak: emozio positiboa, balentzia, psikologia positiboa, zabaldu-etaeraiki teoria, emozio positiboaren alde argiak, emozio positiboaren alde ilunak.

Emozio positiboak izango ditut aztergai lan honetan. Landu nahi ditudan puntuak, berriz, honako hauek dira: emozio positiboak eta emozio negatiboak bereizteko erabiltzen den irizpidea; zer leku eskaini izan dieten psikologoek emozio positiboei emozioaren historian; eta, azkenik, zer aurkitu duen ikerketak emozio positiboen alde eta zer horien kontra. Baina gaiari heldu baino lehen, emozio positiboetako bat aipatu nahi dut hemen, lanaren hasieran, neure ekarpentxoa egiteko aldizkariaren zenbaki honek Jesus Mari Larrazabal jaunari eskaintzen dion omenaldian. Emozio positibo hori esker ona da, David Steindl-Rasten arabera «bizitza zoriontsuaren giltza» ${ }^{1}$ omen dena. Neure esker ona erakutsi nahi diot, bihotzez, Jesus Mari Larrazabal lagun eta adiskide onari. Ez zait horretarako arrazoirik falta. Berak sortu eta bultzatutako ILCLIko kide izatera gonbidatu ninduen institutua abian jarri zen unean berean; ni bertako Kontseiluko kide izendatua izateaz arduratu zen; hainbat ekintzatan, kongresu, ikastaro eta abarretan parte izateko aukera eman zidan; hasiera hartako eraikinean, «Villa Asunción» delakoan, elkarrizketa ugari izan nuen berarekin eta beste kideekin. Bestalde, ILCLIko kide izateari esker, lan franko argitaratu ahal izan dut 2001ean institutuak sortu zuen GOGOA aldizkarian. Eta, noski, eskerrik beroenak eman behar dizkiot, erretiroa hartu nuenean, ILCLIren izenean Jesus Marik berak eta Kepa Kortak eskaini zidaten liburuagatik (Korta eta Larrazabal 2011). Liburuaren epilogoan idatzi nituen hitz batzuk ekarri nahi ditut hona:

Eskerrak zor dizkiet liburuan parte hartu duten guztiei ... Baina eskerrak Jesus Mariri eta Kepa Kortari zor dizkiet modu berezian. «Gogoratzea bakarrik ez da gutxi», Lasarteren hitzetan; baina Jesus Marik gogoratzeaz gainera, proiektua abian ere jarri zuen. Nirekin hitz egin zuenerako, proiektua aurkeztua zuen ILCLIko kontseiluan eta honek onartua ere bai, baita Euskararako Errektoreordeak ere. Nire oharrei ez zien kasurik egin, noski; zorionez, esango nuke orain. (Huizi 2011: 401-402)

\footnotetext{
1 «[T]he key to a happy life» (ikus Ahrens \& Forbes 2014: 343).
} 
Esker onarena bukatzeko, esan dezadan, ILCLI hasi zenetik izan ditugun harremanetan beti iruditu zaidala Jesus Marik konfiantza zuela nigan. Eskertzekoa da hori eta zinez eta benetan eskertzen diot.

Eta orain bai, artikuluaren gaiari helduko diot. Eta, hasteko, esan dezadan zerbait emozioaz. Giza esperientziaren beste alderdi askorekin gertatzen den bezala, emozioa erraz da ezagutzen baina gaitz definitzen. «Emozioaren definizio zehatza eztabaidagai da, hortaz», esaten nuen aldizkari honetan bertan agertu zen beste artikulu batean (Huizi 2016: 160). Dena dela, lan honen gaia diren emozio positiboak emozioak baitira, egoki izango da emozioari buruz azalpenen bat edo beste ematea. Eta aurrena Giza Fisiologiako katedraduna den Morak Neuroeducación liburuan emozioaz dioenaz baliatuko naiz, batez ere kontuan hartzen duelako berehala aztertu nahi dudan «balentzia» kontzeptuak adierazten duena, kontzeptua bera aipatzen ez duen arren. Emozioa esaten diogun erantzunak barne hartzen ditu gorputzean gertatzen diren aldaketak, pertsona inguratzen duen estimulu sail zabal batek eraginak. Aldaketa hauek emozioa eragiteko gaitasuna duten estimuluak gogoratze hutsetik ere etor daitezke. Estimulu horiek, bestalde, «saria (plazera) edo zigorra (mina) adierazten dute» (Mora 2017: 70)².

Gauzak gehiago zehaztuz esan dezaket, Campos eta Keltnerrekin (2014), emozioak erantzun oso azkarrak eta automatikoak direla, pertsonalki garrantzitsuak diren estimuluek eraginak, eta aldaketa fisiologikoak dituztela lagun. Ikuspuntu kognitiboa hartzen dutenen arabera, emozioen garrantzia honetan datza: harremanetan jartzen dituztela kanpoko gertakari eta pertsona batzuk gure barneko arazo eta kezkekin. Ikuspegi kognitibotik begiratuta, «emozioa balio-judizioa da» (Oatley eta Johnson-Laird 2013: 1) ${ }^{3}$ : gertaera jakin bat garrantzizkoa dela, adibidez, edo pertsona jakin batekin egotea atsegina dela. Emozioa, hortaz, ebaluazioa da, ingelesez «appraisal» esaten zaiona. Eta ebaluazioa denez, emozioak berebiziko garrantzia du, oraintxe aipatu ditudan autore horien arabera; izan ere, guztiz iragartzerik ez dagoen mundu batean bizi garenez, ongi aztertu behar ditugu eta ebaluatu eguneroko gertaerak eta, baita, harremanak ditugun jendea ere.

Aurreko paragrafoan emozioei buruz esan dena emozio guztiei dagokie, baita emozio positiboei ere. Baina «positiboak» esaten badiegu, zergatik esaten diegu horrela eta zertan bereizten dira positiboak ez direnetatik? $\mathrm{Hu}-$ rrengo puntuan ariko naiz horretaz.

\footnotetext{
2 «[I]ndican recompensas (placer) o castigo (dolor)» (Mora 2017: 70)

3 «[A]n emotion is a judgment of value» (Oatley eta Johnson-Laird 2013: 1). Autore hauek, emozioa balio-judizioa dela esan ondoren, Aristotelesen Erretorika liburua eta horko 1378a zenbakia aipatzen dituzte, hor Aristotelesek emozioen definizioan esaten baitu emozioek alda ditzaketela gure judizioak.
} 


\section{Emozio positiboak eta emozio negatiboak}

Emozio positiboak eta negatiboak bereizteko erabiltzen den irizpide nagusia balentzia da. Balentziak leku nabarmena du emozioaren arloan: hala adierazten dute, beste askoren artean, orain aipatuko ditudan autoreek. Eta, lehen-lehenik, Barbara Fredrickson aipatu nahi dut, bere ikerketa-lan nagusia emozio positiboei eskaini baitie eta arlo honetan beharbada bera izango baita aditu nagusia. Fredricksonek dioenez, bat datoz denak puntu honetan: «emozio ororen ezaugarri nagusi bat balentzia da, oso ezatsegina denetik oso atsegina denera doan noranzko biko continuum batean» (Fredrickson eta Cohn 2008: 779) ${ }^{4}$. Turowski, Man eta Cunninghamen arabera ere, emozioak berezkoa du «balentzia (positibo/negatiboaren) esperientzia subjektiboa» (2014: 96) ${ }^{5}$. Carver, Scheier eta Johnsonen arabera, berriz, «esperientzia emozional ororen giltzarria» (2014: 44) ${ }^{6}$ da balentzia. Barrettek, bere aldetik, «balentzia bizitza emozionalaren oinarrizko osagaia» (2006: 35) ${ }^{7}$ dela dio artikuluaren tituluan berean. Azken autore honen arabera, gainera, psikologian nonahi aurki omen daiteke propietate hori eta hizkuntza guztietan omen daude atsegina eta atsekabea adierazten dituzten hitzak; emozioaren alderdi hau adierazteko erabili izan diren modu batzuk ere aipatzen ditu: «tonu hedonikoa, onura, umore ona-txarra, plazera-mina, hurbiltzea-saihestea, saritzea-zigortzea, desiragarria-abertsiboa, positiboa-negatiboa» (ibid.: 40) ${ }^{8}$. Eta garaikide ditugun autore horien iritziei aspaldiko batena erantsi nahi diet: Aristotelesena. Honek, bere Erretorika liburuan eskaintzen duen emozioaren definizioan, honela dio: «emozioek ... plazera eta mina dituzte lagun» (Rhetoric: 1378a; aipatzen duena: Leighton 1996)9 ${ }^{9}$ Beraz, Aristotelesen arabera ere, plazera eta mina emozioen nahitaezko osagaiak dira eta, horregatik, bi sailetan banatzen ditu emozioak: batean, berekin mina edo sufrimendua dakartenak, beldurra adibidez, eta bestean berekin plazera dakartenak (ikus, honetaz, Konstan 2000).

Balentziaren garrantziaz aritu zaizkigu autore horiek. Baina, zer da balentzia eta zergatik da garrantzizkoa? Psikologian, estimulu edo egoera jakin bat berez atsegina den ala ez adierazteko erabiltzen da «balentzia» hitza. Emozioen psikologiaren sailean, emozio-egoera batzuen izaera atseginari eta beste batzuen izaera ezatseginari dagokie kontzeptu hori. Poza edo ede-

\footnotetext{
4 «[A] primary characteristic of every emotion is valence on a bipolar continuum from highly unpleasant to highly pleasant.» (Fredrickson eta Cohn 2008: 779)

5 «[i]ncludes the subjective experience of valence (positive/negative)» (2014: 96)

6 «[T] he valence is central to all emotional experience.» (2014: 44)

7 «Valence is a basic building block of emotional life.» (2006: 35)

8 «[H]edonic tone, utility, good-bad mood, pleasure-pain, approach-avoidance, rewardingpunishing, appetitive-aversive, positive-negative.» (ibid.: 40)

9 «[E]motions ... are accompanied by pleasure and pain.» (Rhetoric: 1378a; aipatzen duena: Leighton 1996)
} 
rra dena begiestea atseginak dira berez; horregatik, balentzia positiboa aitortzen zaie. Beldurrak eta tristurak, aldiz, balentzia negatiboa dutela esaten da, atsekabearekin edo ezinegonarekin lotzen baitira gehienetan. Pozak eta ederra begiesteak hurbiltzeko jokabidea eragiten dute, balentzia positiboa dute, hortaz; beldurrak eta tristurak, aldiz, aldentzeko edo urruntzeko jokabidea dakarte eta, horregatik, balentzia negatiboa dute. Erakarri egiten duten emozioei emozio positiboak esaten zaie eta atzera eragiten digutenei emozio negatiboak.

Damasiok (2018: 117) gure organismoan bi mundu mota bereizten ditu: barne-mundu zaharra eta barne-mundu ez hain zaharra. Azken honek ez du interesik hemen; beraz, ez dut deus esango horretaz. Barne-mundu zaharrean bihotza, birikak, digestio-hodia eta larruazala bezalako erraiak eta muskulu lisoak sartzen dira. Barne-mundu horren irudiak «ongizatea» eta «ondoeza», «mina» eta «plazera», edo «taupadak» edo «bihotzerrea» bezalako hitzen bidez deskribatzen ditugula dio Damasiok. Honen arabera, bestalde, irudi horiek dira «sentimenduen oinarrizko osagaiak» $(2018: 118)^{10}$. (Eta, hona iritsi nahi nuen, barne-mundu horren berri balentziak ematen digu). Barnemundu horren egoera, «bizi-egoera» Damasioren hitzetan (ibid.: 147) ${ }^{11}$, nolakoa den erakusten digu balentziak ezinbestean: ona, txarra edo bien arteko mailakoa. Egoera ona denean, positibotzat jotzen dugu; txarra denean, aldiz, negatibotzat.

Baina bizi-egoera ona eta txarra ez ezik, bien artekoa ere izan daitekeela esaten du behin baino gehiagotan Damasiok (ibid.: 147, 151). Hori bat dator, nire ustez, Egintzaren Teoria Kontzeptualak (ingelesez, Conceptual Act Theory delakoak) hipotesi gisa aurreratzen duenarekin. Teoria horren arabera, «emozioak kontzeptualizazio kokatuak dira» (Condon, Wilson-Mandenhall eta Barrett 2014: 17) ${ }^{12}$, hau da, gorputzean gertatzen diren afektu-aldaketen esanahia lotua dago unean uneko egoerari. Alde horretatik, positibotzat jotzen diren emozioen ondorioak aski onak edo kaltegarriak izan daitezke gertatzen diren testuinguruaren arabera. Kontuan hartzekoa da hau emozio positiboen alde ilunei eskainiko diedan atalerako.

Balentziarena bukatzeko, termino horrek psikologian, batez ere emozioei dagokienez, gertakari batek duen erakartzeko (balentzia positiboa) edo uxatzeko (balentzia negatiboa) indarra adierazten du. «Negatibotzat» jotzen diren emozioek (hirak eta beldurrak, adibidez) balentzia negatiboa dute. Po-

10 «[L]os componentes fundamentales de los sentimientos»(2018: 118). Sentimendu hitza ez da, hemen, emozio hitzaren sinonimo; sentimenduak «esperientzia mentalak eta, definizioz, kontzienteak dira» ("son experiencias mentales y, por definición, son conscientes") (Damasio 2018: 147).

11 «[E]l estado vital» (2018: 147)

12 «[E]motions are situated conceptualizations.» (Condon, Wilson-Mandenhall eta Barrett 2014: 17) 
zak, esker onak edo maitasunak, desiragarritzat hartzen baitira, balentzia positiboa dute.

Iradoki berria dudanez gauzak gero gehiago zehaztu beharko badira ere, oraingoz esan daiteke emozio positiboek ezaugarri hauek dituztela: atseginak dira, gehitu egiten dute barneko bakea eta ongizatea, zabaldu egiten dute arretaren esparrua eta horiek garatzen eta hedatzen saiatzen gara. Bestelakoak dira emozio negatiboen ezaugarriak: ezatseginak dira, nahasi egiten dute gure barrena, estuago bihurtzen dute arretaren esparrua (ezin diogu arretarik eskaini une horretan kezkatzen gaituenari baizik) eta emozio horietatik libratzen saiatzen gara. Damasioren arabera (2018: 374), tristura kaltegarri izan daiteke osasunarentzat; esker onak, aldiz, kontrako ondorioa izan dezake.

Ohar bat egin beharra dago hemen. Emozio positiboak atseginak eta negatiboak ezatseginak direla esatean, ez da esan nahi haiek desiragarriak direla eta hauek ez, denek baitute beharrezkoa den betekizunen bat. Esan nahi dena da, emozio negatiboak maiz gertatzen badira, hori ez dela seinale ona; bestela esateko, badela gure bizitzan zerbait ongi ez doana. Hobe, horregatik, maizago gertatzea emozio positiboak negatiboak baino.

Emozio positibo eta negatiboen ezaugarrietako batek arretarekin du zerikusia, arretaren hedadura zabala edo estua izatearekin zehazkiago. Emozioek, dio Morgadok (2010: 84), gure arreta gidatzen dute eta zuzentzen eta, hori eginez, lehentasunak ezartzen dizkiote gure pentsamenduari. Arreta zertan jarri esaten digute, zer den kontuan hartzekoa une horretan. Balentzian ez ezik, arreta mailan ere bada ezberdintasunik emozio positiboen eta emozio negatiboen artean. Azken hauek arreta kezkatzen gaituen hartan biltzen dute eta hartan bakarrik. Beldurrak, adibidez, ez digu uzten arreta beldurra sortzen digun hartan baizik ipintzen. Bestela dira gauzak emozio positiboen kasuan. Atsegin ematen digunaz gainera, inguruko beste hainbat gauza ere kontuan har ditzakegu. Hori dela eta, proposatu zuen Fredricksonek $(2008,2013)$ «Zabaldu eta Eraiki» (Broaden and Build) teoria.

Atal hau bukatzeko, ez dut esan gabe utzi nahi balentziaz gainera badela beste dimentsio bat ere emozioa edo afektua sartzen den egoerak ezaugarritzeko erabiltzen dena. Dimentsio hori ingelesez arousal da eta euskaraz, beharbada, atzartasuna. Dimentsio honek adierazten du norberaren inguruak erne egotea eta kemena izatea eskatzen duela. Horrela, «suhartasuna» eta «baretasuna» egoera positiboak dira biak, baina lehenbizikoa atzartasun edo arousal handikoa da eta bigarrena atzartasun apalekoa. Beraz, hemen emozio positiboez ari naiz, bai atzartasun handikoez eta bai atzartasun apalekoez ere. 


\section{Emozio positiboaren historia}

Ezaguna da emozioek ospe txarra izan dutela historian zehar. Ospe txarra filosofian eta baita psikologian ere. Prozesu «misteriotsu eta irrazionaltzat eduki izan dira, logikaren arlotik at daudenak» (Carver, Scheier eta Johnson 2014: 34)13, «hautatze arrazionala ahultzen dutenak» (Williams eta DeSteno 2014: 207) ${ }^{14}$. Azken autore hauek diote orain dela 30 urte oraindik horrela pentsatzen zela.

Psikologiari dagokionez eta horren hasieran, batez ere Darwin eta James dira aipagarriak emozioei eman zieten garrantziagatik beren ikerketetan. Gero, 1920ko hamarkadan, behaviorismoa nagusitzean, gogo-prozesuak baztertu egin ziren eta horiekin emozioak ere bai. Skinnerren arabera (1962), emozioak «alferrikakoak dira eta gure gogo-baretasunarentzat kaltegarriak» (1962: 102) ${ }^{15}$. Kognitibismoaren aldia hasi zen 1950eko hamarkadaren azken urteetan. Psikologia kognitiboak defendatzen zuen zientzian badagoela gogo-prozesuak aztertzerik. Hala ere, gogamenaren teoria konputazionala zen nagusi orduko psikologia kognitiboan eta eredu horrek ez zuen nonbait leku egokirik aurkitu emozioentzat. Gauzak horrela, esan daiteke ia xx. mende guztian arreta gutxi eskaini zitzaiela emozioei psikologian eta zientzian oro har.

Egia esan, aitortu beharra dago, bai psikologian eta bai, batez ere, psikiatrian, emozio batzuk kontuan hartzen zirela, baina emozio negatiboak beti ere. Psikiatrarengana edo psikologoarengana jotzen zuten pertsonei arazoak sortzen zizkieten emozioak, hain zuzen ere. Adierazgarria da Matthieu Ricardek (2014) eskaintzen duen datu hau, Psychological Abstracts delakoan oinarritua: 1887tik 1980ko hamarkadara bitartean psikologiari eskainitako liburu eta artikuluetan 136.728 titulu omen daude emozio negatiboak aipatzen dituztenak, hira, herstura edo depresioa adibidez, baina 9.510 bakarrik poza, gogobetetasuna edo zoriona bezalako emozio positiboez ari direnak.

Abraham Maslow (1970) psikologo ezagunak 1954an dagoeneko egina zuen ohar hau: psikologiak asko zekiela gure huts eta akatsez, baina gutxi gure ahalmen eta gaitasunez. Eta emozio positiboez hau idatzi zuen: «Emozio positiboak (zoriona, baretasuna...) ez dira nahikoa aztertu» $(1970: 173)^{16}$.

Urte batzuk geroago, 1969an, Bradburn psikologo kliniko eta sozialak hamarkada horretan berak egindako ikerketen berri eman zuen. Ikerketa

13 «[W]ere considered mysterious and irrational..., that were outside the domain of logic.» (2014: 34)

14 «[T]hat undermined rational choice.» (2014: 207)

15 «[U]seless and bad for our peace of mind.» (1962: 102)

16 «The positive emotions (e.g., happiness, calm ...) have not been studied sufficiently.» (1970: 173) 
horietan, arreta eritasun mentalen sintometan jarri ordez, jendearen funtzionamendu positiboan jarri zuen. Horrela, erakutsi ahal izan zuen emozio positiboak eta negatiboak ez direla bakarrik elkarren kontrakoak; gainera, mekanismo ezberdinetatik datozela eta bereiz aztertu behar direla. Orain dela gutxi esan duenez, «aurkikuntza berri garrantzitsua izan zen hura, baina psikologo askok ez zuten onartu, uste baitzuten emozio positiboek eta negatiboek dimentsio bakarraren kontrako muturretakoak izan behar zutela eta ez bi dimentsio independente» (Bradburn 2016: 326) ${ }^{17}$. Eta orrialde berean, geroxeago, honela dio —eta batez ere hitz hauengatik ekarri nahi izan dut hona psikologo honen kasua- : «garai hartan funtzionamendu psikologiko positiboan zegoen interes falta jeneralagatik ...»(ibid.: 326) ${ }^{18}$.

Dena dela, gauzak poliki-poliki aldatuz doaz. Mila bederatziehun eta laurogeiko hamarkadan, Alice Isenek eta haren lankideek (e.g., 1985, 1988) argitara emandako artikulu batzuen tituluan irakur daitezke dagoeneko «positive affect» hitzak. Baina aipamen berezia merezi duena Barbara Fredricksonen 1998ko artikulua da. Emozio positiboez hitz egiten den lehen artikulua da. Hona horren izena: «What good are positive emotions?» (Zer balio dute emozio positiboek?).

Urte horretan berean jarriko ziren Martin Seligman, orduan APA edo Amerikar Psikologia Elkartearen lehendakari zenaren gidaritzapean, psikologia positiboa deituko zitzaion joeraren oinarriak. Bizitzaren alde negatiboak ukatu gabe, alde positiboak nabarmentzen ditu psikologia positiboak. Martin Seligmanek bere Authentic happiness (2002) liburuaren hitzaurrean dio psikologia positiboa hiru habe hauetan oinarritzen dela: emozio positiboaren ikerketan, ezaugarri positiboen eta batez ere sendotasunen eta bertuteen ikerketan, eta erakunde positiboen ikerketan. Horrela, psikologia, urte asko patologia eta sufrimendua ikertzen eman dituena, arreta emozio positiboetan eta zorionean jartzen hasten da. Psikologia positiboa sortu eta indar hartzearekin batera, ikertzaileak hainbat emozio positibo zehazki aztertzen hasi ziren (Smith, Tong eta Ellsworth 2014). Shiotak «bizkor garatuz doan emozio positiboaren arlo gazteaz» $(2014: 52)^{19}$ hitz egiten du. Stellar eta Keltnerren (2014: 336) arabera ere, emozioaren iraultzan berandu heldu bazitzaion ere, aurrerapen handiak egin omen ditu emozio positiboaren ikerketa zientifikoak.

Aldaketa handia izan dela ongi erakusten du Gruber eta lankideen adierazpen honek: «Lehertu berria den interesa dago zorionarentzat eta emozio

17 «This was a major new finding but was rejected by many psychologists who believed that positive and negative emotions had to be the opposite ends of a single dimension rather than two independent dimensions.» (2016: 326)

18 «[B]ecause of a lack of general interest in positive psychological functioning at the time...» (ibid.: 326)

19 «[T]he young and rapidly developing field of positive emotion.» (2014: 52) 
positiboentzat» (Gruber, Devlin eta Moskowitz 2014: 3) ${ }^{20}$. Autore hauen beren lanean, bestalde, esaera hau ere irakur daiteke: "positive emotion zeitgeist» (emozio positiboaren zeitgeista). Reeves eta lankideak ere ez ditu harritzen «emozio positiboa ulertzeko interes gero eta handiagoak» (Reeves, Leibenluft eta Gruber 2014: 434) ${ }^{21}$. Interes hori oraindik piztu berria dela garbi dago, gisa honetako gauzak irakur baititzakegu lan bat baino gehiagotan: «until recently» (adib., Pressman eta Bowlin 2014: 183; Ong, Bonanno eta Bergeman 2014: 274; eta baita arestian aipatu ditudan Gruber, Devlin eta Moskowitz ere, 2014: 4); alegia, oraintsu arte ezin izan zaiela erantzun gisa honetako galderei: zer den emozio positiboa, eta zer rol dagokion horri psikologiaren eta osasunaren arteko loturan.

Azkenik, emozio positiboen gaiari gaur egun ematen zaion garrantziaren frogagarri, bi liburu nabarmenduko nituzke hemen, beste lan eta liburu askoren artean. Biak 2014. urtean argitaratuak dira eta biak askoren artean idatziak. Lehenbizikoaren izena The Handbook of Positive Emotions da eta horren argitaratzaileak Michele M. Tugade, Michelle N. Shiota eta Leslie D. Kirby dira. Berrogeita hamabost egilek parte hartzen dute 27 kapituluk osatzen duten liburuan. Liburu itzalgarri honek emozio positiboez orain ezagutzen denaren, edo hobeki esateko, idatzi zenean ezagutzen zenaren berri ematen du: horien izaera, funtzioak eta ondorioak gizabanakoentzat eta gizartearentzat. Beste liburuak Positive Emotion: Integrating the light sides and dark sides du izena eta argitaratzaileak June Gruber eta Judith Tedlie Moskowitz dira. Jendeak, gehienetan, uste izaten du emozio positiboak, poza eta esker ona adibidez, berez direla onak, baina liburuaren argitaratzaileek zalantzan jartzen dute uste hori, emozio positiboa «egoera jakin batzuetan moldakaitza izan baitaiteke» (Gruber, Devlin eta Moskowitz 2014: 3) ${ }^{22}$. Emozio positiboak alde ilunak ere badituela garbi adierazita dago liburuaren tituluan berean. Emozio positiboaren bi alde horiek aztertu eta aurkeztea da egileen helburua. Liburuak 28 kapitulu ditu eta 54 lankide.

Liburu hauetako lanek eta beste askok azken bi hamarkadetan emozio positiboen arloan egin diren aurrerapenen berri ematen digute. Puntu honetara iritsita, balegoke galdera hau egiterik: Nolatan ez ziren lehenago hasi emozio positiboei buruzko ikerketa-lanak? Iraganean emozio positiboetan arreta gutxi jarri izan bazen, Fredricksonen (2003) arabera, hauek izan daitezke horren arrazoietako batzuk:

20 «There is a recent explosion of interest on happiness and positive emotion.» (Gruber, Devlin eta Moskowitz 2014: 3)

21 «[A] burgeoning interest in understanding positive emotion.» (Reeves, Leibenluft eta Gruber 2014: 434)

22 «[I]t may, under certain conditions, be maladaptive.» (Gruber, Devlin eta Moskowitz 2014: 3) 
- Psikologiak jendearen arazo psikologikoak ulertu eta konpontzeko duen joera da arrazoi bat, arrazoirik orokorrena Fredricksonen ustez; emozio positiboek ere, gero ikusterik izango dugunez, izan dezakete eraginik problemetan, baina mundu honetako sufrimendu askoren kausa emozio negatiboak dira.

— Emozio positiboak, bestalde, negatiboak baino nekezago bereizten dira batzuk besteetatik (haserrea, beldurra eta tristura bereiztea erraza da, ez hain erraza poza, josteta eta baretasuna bereiztea); horregatik, baliteke zailagoa izatea emozio positiboak aztertzea.

- Emozio negatiboek aurpegi-adierazpen bereziak dituzte eta erraz ohar gaitezke nor dagoen haserre eta nor triste edo beldurrez; emozio positiboen kasuan ez dago horrelakorik.

- Ekintzarako joera espezifikoei dagokiena da beste arazo bat. Ezagunak dira emozio negatiboek bide ematen dieten ekintzak: beldurrak ihes egitera bultzatzen gaitu, haserreak erasotzera. Emozio positiboek ez dute horrelako ekintza espezifikorik eragiten.

- Azkenik, begien bistakoa da emozio negatiboek duten balio ebolutiboa: arrisku-egoeran, istant batean uzten dute alde batera bizirik irauten lagunduko ez diguna; emozio positiboei dagokienez, ezin da horrelakorik esan; eboluzioaren ikuspegitik, poza, baretasuna eta esker ona ez dira itxuraz beldurra, hira eta nazka bezain onuragarriak.

Gauzak horrela, zer onura dakarkigute emozio positiboek? Zergatik dago orain halako interesa horietaz gehiago jakiteko? Fredricksonen arabera, emozio positiboek ez digute balio hil edo biziko egoeran, baina badute bestelako baliorik: geroko egoera larrietarako prestatzen gaituzten gogo-egoerak eta jokaerak bultzatzen dituzte.

Dena dela, esan beharra dago, azken urteotan egin den lanak agerian jarri duela argiez gainera itzalak ere badituela emozio positiboak. Hurrengo bi ataletan horietaz ariko naiz: aurrena emozio positiboaren alde zer dagoen ikusiko dugu eta ondoren zer dagoen horren kontra.

\section{Emozio positiboen alde argiak}

Estimu handitan dauzkagu emozio positiboak eta irrika biziz ibiltzen gara horien bila. Maite dugu, noski, ongi sentitzea, baina ez da hori emozio positiboetatik datorkigun onura bakarra, ezta garrantzizkoena ere agian. Izan ere, epe luzeko eta probetxu handiko ondorioak dituzte emozio positiboek zenbait arlotan, ikerketak erakutsi duenez. Hiru arlo aipatzen dituzte Armentia, Fritz eta Lyubomirskyk (2017): lana, osasun fisikoa eta pertsona arteko harremanak. Azkeneko bi horietaz gainera, emozio positiboek kognizioaren arloan duten eragina ere aipatzen dute beste batzuek, Fernández- 
Abascalek (2015) eta Vecina Jiménezek (2006) adibidez, baita Fredricksonek berak ere $(2003,2013)$. Hemen, ondoren aipatzen diren hiru arloetan jarriko dut arreta: osasuna, kognizioa edo pentsamenduaren arloa eta pertsona arteko harremanak.

\section{Emozio positiboak eta osasuna}

«Bihotz alaiak osasuna ekarri, bihotz tristeak hezurrak ihartu» idatzi zuen aspaldi Itun Zaharreko Esaera Zaharrak $(17,22)$ liburuaren egileak. Ideia hori bera gaur emozioen ikertzaileek beste era honetan adieraziko lukete: emozio positiboek mesede egiten diote osasunari eta bizia luzatzen dute. Horren adibide interesgarri bat «Mojen ikerketa» edo «Mojen estudioa» deritzana da, «orain klasikoa den 180 mojaren estudioa» (Moskowitz eta Saslow 2014: $416)^{23}$. Ikerketa horretan parte hartu zutenak mojak izan ziren, Nôtre Dameko Ahizpen kongregazioko 180 moja, zehazki esateko.

Joan den mendeko hogeita hamarreko hamarkadan, moja horien Amerikako nagusiak autobiografia labur bat idaztera gonbidatu zituen, ordura arte beren bizitzan aipagarriena zena kontatzeko eskatuz. Artean oso gazteak ziren lekaime horiek: batez beste 22 urte zituzten eta botoak egin berriak. Autobiografiak artxibatuta gelditu ziren eta, horri esker, ikerketa egiterik izan zen 60 bat urte geroago.

Dokumentu horiek ezagutzeko aukera, Kentuckyko Unibertsitateko hiru psikologok (Danner, Snowdon eta Friesen 2001) zahartzeari buruzko ikerketa bat egitea erabaki zutenean izan zen. Estudioan parte hartzeko prest agertu ziren mojetatik Ipar Amerikan jaioak eta bertan hazi eta heziak ziren 180 aukeratu zituzten.

Bizia zerk duen laburtzen eta zerk luzatzen nahi zuten aztertu ikerketaren egileek. Eta mojak aukeratu bazituzten, haien bizimodua ongi neurtua eta babestua zelako izan zen: dieta bera, ordutegi bera, eta abar. Era horretan, bazterturik geratzen ziren nahasketa sor zezaketen faktore gehienak. Eta, hala ere, ikusten bazen aldeak zeudela mojak bizi ziren urte kopuruan, zergatik gertatzen ote zen hori? Ikertzaileek autobiografien testuak hartu eta emozio positiboak, negatiboak eta neutroak adierazten zituzten hitz eta esaldiak bilatu zituzten. Batez ere emozio positiboak hartu zituzten kontuan.

Aurkikuntza nagusia honako hau izan zen: lotura handia zegoela gaztetan idatzitako autobiografien eduki positiboaren eta mojen longebitatearen artean 60 urte geroago. Beste era batean esanda, emozio positibo gehiago adierazi zituztenak bederatzi urte eta erdi inguru gehiago bizi izan zirela

23 «[N]ow classic study of 180 nuns» (Moskowitz eta Saslow 2014: 416) 
emozio positibo gutxiago adierazi zituztenak baino. Seligmanek, gorago aipatu den liburuan, ikerketa honen kontakizuna honela bukatzen du: «Badirudi zoriontsua den moja luzaz biziko dela» (2003: 19) ${ }^{24}$.

Ikerketa hau ez da kasu bakana. Beste zientzialari batzuek ere frogatu dute ongi sentitzen zirenak luzaroago bizi izan zirela. Pressman eta Cohenek (2012), adibidez. 1960ko hamarkadan, psikologiaren historia bat agertu zen, zazpi liburukitan, psikologo ospetsu askok autobiografia moduan idatzitako lanez osatua. Pressman eta Cohenek ordurako hilak ziren psikologo horietako 88ren autobiografiak aztertu zituzten. Mojen estudioan ez zen bereizketarik egiten emozio positiboak adierazten zituzten hitzen artean. Ikerketa honetan, aldiz, hitzen balentziaz gainera horien arousal edo aktibazioa ere kontuan hartu zen. Horrela, aktibazio handiko hitzak eta aktibazio apaleko hitzak bereizi ziren. Adibidez, aktibazio garaiko hitz positiboak dira honako hauek: alaia, zoriontsua, kementsua, bihoztuna, irrika, harrotasuna. Beste hauek, positiboak badira ere, aktibazio apalekoak dira: lasaia, barea, baketsua, atsegina, eztia, trankila. Ikerketa honen garrantzia honetan datza, hots, osasunarekin eta longebitatearekin zerikusia duten hitzak aktibazio edo arousal handiko hitzak direla.

Moskowitz eta Saslowen arabera (2014), datu horiek euskarri sendoa dira hipotesi honentzat: "afektu negatiboaren edozein ondorio gorabehera, afektu positiboa modu berezian dago lotua bizitza luzeagoarekin» (2014: 416-417) ${ }^{25}$.

Beste ikerketa asko ere hona ekartzerik izango nuke, baina nahikoa izango da bat edo beste aipatzea, horietatik atera diren ondorioen berri laburki adieraziz. Aurrena, esan dezadan zerbait Ostir eta lankideenaz (Ostir et al. 2000). 65 urtetik gorako 2.282 lagunen osasun-egoera aztertu zuten bi urtez. Emaitzek erakutsi zuten emozio positiboak babesgarri gertatzen zitzaizkiela adineko pertsonei zahartzearen eta ezintasunaren kontra; baina ez hori bakarrik, zein biziko ziren eta zein hilko ziren ere aurresaten zuten.

Fredrickson eta Cohnek, 2008an, «emozio positiboak fisiologiarekin lotzen dituzten frogez» (2008: 788) ${ }^{26}$ hitz egiten zuten. Eta zenbait ikerketatan aurkitutako emaitzak ere aurkezten zituzten laburki, horietako bi ikusi berri ditugunak, Danner eta lankideena eta Ostir eta lankideena, emozio positiboek luzaroago bizitzen laguntzen dutela iradokitzen dutenak. Horiei emozio positiboen beste onura hauek adierazten dituztenak eransten dizkiete: min eta ezintasun gutxiago sentitzea osasun-egoera kronikoetan eta gaixotasunari arrakastaz aurre egitea.

\footnotetext{
24 «I]t seems that a happy nun us a long-lived nun.» (2002: 4)

25 «[P]ositive affect is uniquely associated with longer life, independent of any effect of negative affect.» (2014: 416-417)

26 «[E]vidence linking positive emotions to physiology.» (2008: 788)
} 
Azkenik, emozio positiboen eta osasunaren arteko loturari eskaini diodan puntu hau bukatzeko, aipamena bederen egin diezaiodan Fredricksonen ekipoak (Kok et al. 2013) egina den ikerketa bati, non egiaztatu ahal izan zuten emozio positiboek, gizarte-harreman positiboek eta osasun fisikoak elkarri eragiten diotela goranzko espiral dinamiko eta positibo bati bide emanez. Gauzak honela gertatuko lirateke: emozio positiboen eraginez harreman sozial positiboak hautematen dira, horren ondorioa osasun fisikoaren hobekuntza da (nerbio bagoaren tonuaren adierazlearen bidez neurtzen dena) eta nerbio bagoaren tonuak gora egiteak jendeak emozio positibo gehiago sortzea dakar. Hemen merezi du nabarmentzea, harrigarria delako, osasun fisikoa gehitzeak emozio positiboak sortzen laguntzen duela.

\section{Emozio positiboak eta kognizioa}

Emozio positiboen eta kognizioaren arloaren arteko loturaz hitz egiten hastean, nahitaez aipatu behar dira Alice Isenek gaiari egindako ekarpenak. Arrazoiz diote Positive Emotion: Integrating the light sides and dark sides liburuaren argitaratzaileek «osatugabea izango litzatekeela emozio positiboaz ari den liburu bat Alice Isenen lana gabe» (Moskowitz et al. 2014: 72) ${ }^{27}$. Eta kapitulu bat eskaintzen diote gorazarretan, Isenen lankide izandako bi lagunekin batera. Bazuen Isenek liburu horretan parte hartzeko asmoa eta puntu honetan hizpide dudan gaiaz, hain zuzen ere. Kapituluaren egileen arabera, Isenek asmo hau zuen: «afektu positiboak kognizioa eta auto-kontrola hobetu egiten dituela frogatzen duen literaturaren sintesia eta azterketa eskaintzea» (ibid.: 72) ${ }^{28}$. Baina 2012an «passed away», hil egin zen.

Hogeiren bat urteko epean Isenek eta lankideek zuzendutako esperimentuek erakusten dute, jendeak afektu positiboa (edo emozio positiboa) sentitzen duenean, haien pentsatzeko modua ezohikoa dela: malguagoa da, sortzaileagoa, integratzaileagoa (material desberdinak integratzeko gaiagoa), informazioari sentiberagoa eta eraginkorragoa (Fredrickson 2001). Fredricksonen arabera, Isenen lanean garbi ageri da «afektu positiboak zabaldu egiten duela kognizioa» (ibid.: 221) ${ }^{29}$. Isenen lantaldeak antolatutako esperimentu batean, adibidez, parte-hartzaileak jardunean zeuden medikuak izan ziren. Haien arrazoibide klinikoa aztertu nahi izan zen. Haietako batzuei, ongi senti zitezen, gozoki poltsatxo bana eman zitzaien (baina esperimen-

\footnotetext{
27 « $[\mathrm{N}]$ o book on positive emotion would be complete without the work of Alice Isen.» (Moskowitz et al. 2014: 72)

28 «[A] synthesis and review of the literature demonstrating that positive affect improves cognition and self-control.» (ibid.: 72)

29 «[P]ositive affect broaden cognition.» (ibid.: 221)
} 
tuak irauten zuen bitartean ez zeukaten jaterik) eta, ondoren, eskatu zitzaien goraki pentsatzeko gibeleko gaitza zuen gaixo baten kasua ebazten zuten bitartean. Edukien analisiek erakutsi zuten lasterrago integratzen zutela kasuari zegokion informazioa eta ez zirela besteak (gozoki poltsatxorik eman ez zitzaienak) bezain lerrakorrak hasierako pentsamenduetan oinarritzera edo ondorioak behar baino lehenago ateratzera.

Isenen lanean eta bere ikerketetan oinarriturik, Fredricksonek (2001, 2003) «zabaldu-eta-eraiki» eredu edo teoria moldatu zuen, helburu honekin moldatu ere: azalpen bat eskaintzea emozio positiboek kognizio mailan - eta, gero ikusterik izango dugunez, baita harreman sozialen arloan eredituzten ondorio indartsuak. Teoriak bi atal edo hipotesi ditu: «zabaldu» hipotesia eta «eraiki» hipotesia. «Zabaldu» hipotesiak esan nahi du emozio positiboek «zabaldu» edo hedatu egiten dutela jendearen arreta eta pentsamendua; jendeak, horrela, arreta ipintzen du lehen ohartu gabe zegoen gauzen arteko lotura eta harremanetan. Eta orain lehen ez bezalako aukera du «baliabide» berriak aurkitzeko. Fredricksonen «baliabideak» funtsezko trebetasunak dira, jendearen bizitza gogobetekoagoa izatea dakartenak. Baliabideak gehitzea teoriaren «eraiki» parteari dagokio. Haur-jolasaren adibidea jartzen du Fredricksonek (2003: 333). Hori ez da denbora-pasa hutsa, berehalako helburua ongi pasatzea bada ere. Jolastuz, haurra ikusten eta ikasten ari da. Ikusten nola jokatu behar den, zein estrategia diren egokiak eta zein ez, zer onartzen duten lagunek eta zer ez; bestalde, jarduera fisikoak mesede egiten dio gorputzari. Eta ikasi egiten du, beste hainbat arlotan onuragarri izango zaizkion baliabideak eskuratuz: adimen-baliabideak, baliabide psikologikoak eta sozialak. Jolastuz, bizitzako arazoei irtenbide egokia emateko estrategiak lantzen ditu. Aintzat hartzekoa da Morak (2017) haur jolasaz dioena: «Jolastea ikasteko bide bat da, ikasteko aitzakia bat» (2017: 78) ${ }^{30}$, «izadiaren asmakizun indartsu bat... ikastearen armarik ahaltsuena» (2017: 79) ${ }^{31}$, jakin-mina eta atsegina, biak baititu osagai.

Afektu edo emozio positiboak pentsamendua sortzaileago egiten duela ikusi dugu. Puntu hau bukatzeko, ikus dezagun zer dioen Morgadok (2010: 128) sormenaren eta emozio positiboen arteko loturaz. Sormenaren ezaugarria berritasuna dela esanez hasten da. Berritasuna gertatzeko, gainera, nahikoa omen da askotan sortzailearen buruan lehendik dauden ezaguerak modu berrian konbinatzea (Fredricksonen teoriaren «zabaldu» partean sartuko litzateke hori). Ezaguera horiek gehitzeak esan nahiko luke gehitu egiten dela lotura berriak sortzeko aukera. Beraz, ez da harritzekoa emozio positiboek sormenari bultzada ematea. Izan ere, emozio positiboen ondo-

\footnotetext{
30 «Jugar es un medio, una excusa, a través de la cual se aprende.» (2017: 78)

31 «[E]s un invento poderoso de la naturaleza ... El arma más poderosa del aprendizaje.» (2017: 79)
} 
rioetako bat umorea hobetzea da eta jendeak, orduan, gauza gehiagotan jar dezake arreta; eta, horren eraginez, handitu egiten da gauza ezberdinen artean loturak ezartzeko aukera. Honako hau ere ikusterik izan omen da, hots, umore positiboak gehitu egiten duela jendearen buru-malgutasuna. Azkenik, bi gauza esaten dizkigu geure burua aztertzeko balio diezaguketenak. Lehenbiziko gauza da pertsona sortzaileak oso sentiberak izaten omen direla, eta bigarrena, zenbat eta positiboagoa izan gure umorea, orduan eta handiagoa izango dela gure sormena.

\section{Emozio positiboak eta pertsona arteko harremanak}

Hemen ere Alice Isen aipatuz hasi behar dut. Izan ere, bere hasierako lanetan dagoeneko erakusten du gai honi buruzko interesa. Aurkitu ere aurkitu zuen afektu positiboa sentitzeak gehitu egiten zuela besteei laguntzeko joera (Isen 1987). Hori egiaztatzeko antolatu zuen ikerketan (Isen 1970; Isen eta Levin 1972), esperimentuko parte-hartzaile batzuek txanpon bat aurkitzen zuten telefono-kabina bateko artekan, eta besteek ez. Txanponak, noski, ikertzaileek jarriak ziren. Txanpona aurkitu zuten gehienek lagundu zioten laguntza behar zuenari: liburu karga handia eramaten edo lurrera erori zitzaizkion paperak jasotzen. Txanpona aurkitu ez zutenetatik, oso gutxik lagundu zieten laguntza behar zutenei. Beraz, txanpona aurkitzeak eta horrek eragindako emozio positiboak jendea altruistago egin zuen. Pozak ere handitu egiten du besteei dagokienez modu positiboan jokatzeko probabilitatea eta harreman positiboagoak eraikitzea dakar. Kok eta lankideek (2013), bestalde, honako hau aurkitu zuten: emozio positiboek, harreman sozial positiboek eta osasun fisikoak elkarri eragiten diotela.

Fredrickson eta Cohnen arabera (2008), pertsona arteko harremanen arloan «zabaldu eta eraiki» teoriaren zabaldu hipotesiari, batetik, besteengan arreta handiagoa ipintzea dagokio eta, bestetik, norberaren eta besteen arteko ezberdintasunak gutxitzea. Bestalde, emozio positiboak sentitzen dituztenen kasuan beren buruaz duten ideiaren eta beren lagunik onenaren ideiaren artean dagoen aldea txikiagotu egiten da eta gehiago kezkatzen dira lagunen alde egin dezaketenaz. Emozio positiboen beste ondorio bat talde sozialen kontzeptuak zabaltzea omen da: horrela, «besteen eta gure artean» bereizteko dugun joera deuseztatu egingo litzateke.

Yee eta lankideen lanean (2014: 215) irakur daiteke teorialari batzuek proposatu duten hau: emozioen bilakaeraren helburua, neurri handi batean, gure besteekiko harremanak erregulatzea izan dela. Eta horren alde agertu diren hainbat teorialari aipatzen dituzte, Keltner eta Haidt 1999; eta Keltner eta Kring 1998, adibidez. Horregatik, ez omen da harritzekoa psikologia sozialean luzaroan aztertu izana emozioei harremanetan dagokiena. Hori ulertzen lagun diezaguke Morgadok (2010: 94) emozioen eboluzioaz dioenak: 
«eboluzioan zehar, are hizkuntza mintzatua agertu baino lehen, emozioak komunikabide indartsu bihurtu ziren» (2010: 94) ${ }^{32}$.

Azkenik, Fernández-Abascalek (2015), afektu positiboak eta pertsona arteko harremanek lotura hertsia dutela baieztatu ondoren, arlo honetan sartuko litzatekeen gai bat azaltzen du, irribarrearena. Sauter eta lankideek (2014) orrialde sail bat eskaintzen diote gai horri. V. Simónen (2017) liburuan ere aurki daitezke bizpahiru orrialde irribarreaz eta giza harremanekin duen zerikusiaz. Fredricksonek eta Levensonek (1998) egindako esperimentu baten berri ere ematen du eta hor aurkitu zutena kontatuz amaituko dut atal hau. Esperimentuko parte-hartzaileengan emozio negatiboak eragiten zituzten bideo batzuen bidez. Bideoak ikusten ari ziren bitartean berez irribarre egiten zutenak —ikertzaileek horretarako ezertxo ere egin gabe, alegia- egiten ez zutenak baino lehenago itzultzen ziren aktibazio kardiobaskularraren maila normalera. Irribarreak, hortaz, estresaren kontrako babesa eskaintzen zuen.

\section{Emozio positiboen alde ilunak}

Orain dela gutxi, Gruber eta Purcellek (2015: 1) galdera hau egiten zuten: «Emozio positiboa beti ona al da guretzat?» ${ }^{33} \mathrm{Bi}$ autore horietako lehenak erantzuna emana zuen, urtebete lehenago, beste lankide batzuekin. Han esaten baitzuen emozio positiboak, helburu garrantzizkoak lortzea errazteaz gainera, bazuela beste aukera inportante bat ikerketak alde batera utzia zuena; honako hau: emozio mota hori, «egoera jakin batzuetan, desegokia izan daitekeela» (Gruber, Devlin eta Moskowitz 2014: 3) ${ }^{34}$. Bestela esateko, argiez gainera, itzalak ere izan ditzaketela emozio positiboek.

Positive emotions: Integrating the light sides and dark sides (2014) liburuaren helburu nagusietako bat emozio positiboen «alderdi ilun» horren adibide enpirikoak ematea izan da. Adibide horien berri ematen saiatuko naiz hemen.

Condon eta lankideek, liburuaren 2. kapituluan, egoeraren garrantzia azpimarratzen dute: «Egoerek erabakitzen dute jokabideak «positiboak» diren» (Condon et al. 2014: 20) ${ }^{35}$. Horrela, barkatzea, optimismoa edo adeitasuna, ongizatea iragartzen dutenak, kaltegarri ere gerta daitezke zenbait egoeratan. Autore hauek diotenez, «emozio «positibo» eta «negatiboak» ez dira berez positibo edo negatibo» (ibid: 20$)^{36}$. Bestalde, negatibotzat dauzkagun emozio

\footnotetext{
32 «[E]n el curso de la evolución, incluso antes de que apareciera el lenguaje hablado, las emociones se convirtieron en un poderoso medio de comunicación.» (2010: 94)

33 «Is positive emotion always good for us?» (2015: 1)

34 «[T]hat it may, under certain conditions, be maladaptive.» (Gruber, Devlin eta Moskowitz 2014: 3)

35 «Situations determine whether behaviors are "positive".» (Condon et al. 2014: 20)

36 «[P]ositive» and «negative» emotions are not inherently positive or negative.» (ibid: 20)
} 
batzuk mesedegarriak izan daitezkeela diote, eta Forgas eta lankideek (Forgas, Goldenberg eta Unkelbach 2009) aurkitutakoa aipatzen dute: egoera ezatseginek hobetu egin zutela oroimen-ariketa bateko lana. Condonek eta, ondorio orokor bat eskaintzen dute: «edozein emozio-kategoriak hainbat jokabide dauzka aukeran, batzuk mesedegarriak edo kaltegarriak ongizatearentzat testuinguruaren arabera» $(2014: 21)^{37}$. Behin eta berriz esaten duten gauza bat da afektu atseginak ez dakarrela beti ongizatea. Horren adibide dira nahasmendu bipolarra eta baita, uste denez, droga-mendekotasuna ere; kasu horietan gehiegizkoa izango litzateke afektu atsegina.

Oso kontuan hartzekoa da Carver, Sheier eta Johnsonek (2014, 3. kapitulua: 45) emozio positiboaren alde argiez eta alde ilunez diotena: emozio positiboaren alde argia emozioak sortzen duen esperientzia atsegina dela, baina esperientzia horrek iraungitze-data duela; horregatik, emozio positiboaren alde iluna esperientzia horri gehiegi iraunarazi nahi izateak eragiten du, edo esperientzia hori biziago egiten saiatzeak.

Emozio positiboen alde ilunei dagokiena bi eratan aurkeztuko dut. Lehenbizi, emozioz emozio, ikusiz joango gara zer aurkitu duten autoreek aztertu dituzten emozioetako bakoitzean. Ondoren, Gruberrek eta Purcellek (2015) alde ilunak nolabait sailkatzeko proposatu dituzten sei gaiak eskainiko ditut labur-labur.

\section{a) Emozio positiboen alde ilunak emozioen arabera}

Campos eta Keltnerrek (2014) zortzi emozio positiboren alde argiak eta ilunak azaltzen dituzte banan-banan. Horietako bat («contentment», ingelesez) ez dago garbi, dirudienez ezta autoreentzat ere, nola ulertu behar den eta ez dut hemen kontuan hartuko. Hemen, beste zazpi emozioen alde ilunak aipatuko ditut eta autore hauek esaten dutenari beste batzuek emozio horietako bakoitzari buruz esaten dutena ere erantsiko diot. Hona, bada, zazpi emozioak (Campos eta Keltner 2014: 63-66):

— Josteta («amusement», ingelesez). Jostalaria denaren egoera adierazten du. Emozio honen garrantzizko osagai bat umorea da eta hau besteak gaitzetsi edo gutxiesteko erabil daiteke, horrela jostetaren alde ilunari bide emanez. Samson eta Gross (2014), 10. kapituluan, umorearen alde on eta txarrez ari dira. Erreakzio negatibo sail bat eragin dezakeela diote hor. Batzuetan, galgarria izan daiteke, iraintzat edo erasotzat hartzen bada. Bestalde, kontraesanezko emozio-egoerak sor omen ditzake.

\footnotetext{
37 «In general, any given emotion category contains a range of behaviors, some beneficial or detrimental to well-being depending on context.» (2014: 21)
} 
Ostrazismora behartzeko erabil daiteke eta «bullying» delakoaren osagaietako bat izan daiteke. Platonek, Aristotelesek eta Hobbesek umorea eta baita barrea ere erasoarekin, mespretxuarekin eta gehiagotasun-usteekin lotzen zituztela gogoratzen digute.

- Harridura («awe», ingelesez). Inguruneko harrigarriek eragiten duten txikitasun-sentimenduari dagokio. Autoreek alde ilun posible bezala hau aipatzen dute: mirespena eragiten duten irudi eta erakunde indartsuei amen esatea, beste batzuentzat edo norberarentzat kaltegarri dena agintzen digutenean. Horren adibidetzat, obedientziari buruzko Milgramen ikerketa klasikoak jartzen dituzte.

- Esker ona («gratitude», ingelesez). «Mesede edo zerbitzu bat hartu duenaren ezagutzazko sentimena» (Euskaltzaindia 2012). Campos eta Keltnerren arabera, arreta gutxi eskaini zaie esker onak izan ditzakeen eragin negatiboei. Hala ere, beraiei bi aukera bururatzen omen zaizkie. Lehenbizikoa da esker ona kulpa eta atsekabe bihurtzea mesedeei erantzuteko modurik ez dagoenean. Eta emakume etorkinen kasua aipatzen dute; izan ere, hasierako egoera zailean laguntza eskaini zietenentzat esker onez beterik egon arren, ez dira gai izango hartutako mesedeei erantzuteko. Beste alde ilun bat esker onak izan dezakeena gehiegizko esker ona sentitzea omen da; horren ondorioz, manipulazio emozionala gertatzeko arriskua egongo litzateke.

- Interesa («interest», ingelesez). Berria den zerbait aztertzeko gogoa eta aztertzeko gai garelako sentimena pizten duen egoera da. Gure autoreek diote interesaren alde ilun bat izan daitekeela arreta gehiegi jartzea helburu batean, beste aukera batzuk alde batera utziz.

— Poza, alaitasuna («joy», ingelesez). Pozaren alde ilunen artean aipatuena nahasmendu bipolarrari dagokiona da. Nahasmendu psikiatriko kroniko larria da hori eta horren ezaugarria, aldi maniakoan, umore positibo anormal eta iraunkorra da. Aldi horretan, emozio positibo desegoki eta ezin gehiagokoak dituzte etengabe gaixotasun hori dutenek (Gruber eta Purcell 2015). Gehiegizko pozak eta zorionak, bestalde, arrisku handiko jokabideak eragin ditzake: alkohol-abusua, betekadak, drogak erabiltzea eta kontuan ez hartzea bere inguruan dituen arrisku handiak. Beraz, poz betearen edo «zorionaren eta ondorio mesedegarrien arteko lotura ez da lineala» diote Gruber eta Purcellek (2015: 3) ${ }^{38}$. Ford eta Maussen arabera ere (2014: 376), duela gutxi egindako ikerketek iradokitzen dutenez, zoriontsu izan nahiak emaitza negatiboak erakar ditzake: ongizate gutxiago, osasun psikologiko kaskarragoa eta zorion gutxiago. Forgasek, bestalde, 17. kapituluan (2014: 301-322), espero zitezkeen emaitzen kontrakoak aurkitu dituzten esperimentuen berri ematen du. Umore positiboak, adibidez, gehitu egiten 
du self-handicapping delakoa edo nork bere buruarentzat handicapak sortzea bere erantzukizuna saihesteko; gutxitu egiten du jarraikitasuna; batzuetan kalte egiten dio kognizioari, oroimenari bereziki eta, ondorioz, hainbat prozesu kognitibo konplexuri (ideiak lotzeari, inferentziak egiteari edo judizioak eratzeari); sineskortasuna gehitzen $\mathrm{du}$ eta eszeptizismoa gutxitzen; jendetasuna gutxitzen du; berekoikeria handi dezake, eta abar. Forgasek eskaintzen duen emozio positiboen ondorioen panorama ez da oso erakargarria, egia esan. Dena dela, kontuan hartzekoa da lanaren bukaeran esaten duena: «Aitortu behar dugu, hala ere, desiragarriak ez diren ondorio hauek afektu positiboak egoera batzuetan bakarrik eragiten dituela, eta beste batzuetan ez» $(2014: 317)^{39}$.

- Maitasuna («love», ingelesez). Maitasunaren alde ilunak alde argiak baino gutxiago aztertu dira. Hala ere, egin diren ikerketek Campos eta Keltnerren arabera (2014: 65) erakusten dute, batetik, erantzunik gabe gelditzen den maitasuna esperientzia mingarria dela eta, bestetik, norberaren premiak aintzat hartzen ez dituen maitasuna kaltegarria izan daitekeela osasun fisiko eta mentalarentzat. Bestalde, bizitzan ongi sentitzeko badirudi maitasunak diadikoa, elkarrenganakoa eta gizarteak onartua izan beharko lukeela.

- Harrotasuna («pride», ingelesez). Itziar Etxebarria, Susana Conejero eta Aitziber Pascual adiskideek idatzitako lan batek izenburu hau du: «Harrotasuna, aurrera egiten laguntzen digun adiskidea (bere berezitasunekin ...)». Lan horren egileek esaten dutenez, «harrotasuna pertsonak bere jokabideari buruz ebaluazio positiboa egiten duenean sortzen da» (Etxebarria, Conejero eta Pascual 2011: 153). Alde ilunean, harrotasun «hubristikoa» deritzana nartzisismoarekin eta honek pertsona arterako dituen alde txarrekin lotu izan da. Izan ere, hubris delakoak, oraintxe aipatu ditudan autoreek diotenez, «neurriz gaineko harrotasuna adierazten du» (ibid: 153). Harrotasun hubristikoa sentitzen dutenek besteen gainetik daudelako ustea dute eta enpatia gutxi erakusten dute beraiek bezalakoak ez direnen aldera (Tracy et al. 2014: 303). Bestalde, badirudi, ikerketa batzuen arabera, harrotasun maila altua erakusten dutenek arrisku handiagoa dutela nahasmendu bipolarra garatzeko (ibid.: 306).

Campos eta Keltnerrek kontuan hartu dituztenez gainera, Fredricksonek beste bi emozio ere aztertu zituen: baretasuna eta itxaropena. Azkenaldi honetan asko hitz egiten den beste emozio batzuk ere badaude, errukia eta enpatia horien artean. Errukiari, adibidez, kapitulu bat eskaintzen zaio The handbook of positive emotions liburuan.

39 «We need to recognize, however, that positive affect only produces these undesirable consequences in some situations, and not in others.» (2014: 317) 


\section{b) Emozio positiboen alde ilunak gaien arabera}

Gruberrek eta Purcellek (2015) sei gai nagusitan biltzen dituzte emozio positiboek izan ditzaketen ondorio ez desiratuak. Bada, sei gai horiek aurkeztuz emango diot amaiera atal honi:

- Neurria: Zenbat eta emozio positibo gehiago, orduan eta hobe ote? Ezezko erantzuna dagokio, noski, galderari. Adibidez, emozio positibo altua duen jendeak jokabide oso arriskutsuetan nahasteko joera du; bestalde, nahasmendu bipolarraren seinale izan daiteke.

- Egoera: Emozio positiboak noiz eta non? Emozio positiboa ez genuke sentitu behar, ez edozein unetan eta ez edozein lekutan ere. Kasu bat aipatzen dute: umore ona eragin zitzaienak okerrago aritu ziren konputagailuko lehiaketa-joko batean umore txarra eragin zitzaienak baino.

-Espezifikotasuna: Emozio positibo guztiak ez dira berdinak. Askotan «emozio positiboaz» hitz egiten da, singularrean, batez ere ikerketatestuinguruan, baina praktikan gauzak ez dira horrela. Harrotasuna ona izan daiteke testuinguru batzuetan, sari bat irabazi denean adibidez, baina meritu berezirik gabeko egoeran, emaitza sozial negatiboak ditu.

- Autorregulazioa: Emozio positiboak erabiltzeko gauza ez? Emozioa era moldagarrian erregulatzeko gaitasunak aldeko osasun-emaitzak dakartza, ongizate handiagoaz gainera; norberaren emozioak erregulatzeko gaitasun gutxi edo batere ez izatea, aldiz, osasun mental moldakaitzarekin lotzen da. Emozioak kontrolatzeko gaitasuna batez ere emozio negatiboen kasuan aztertu da, baina emozio positiboetan ere arazoak badaude; esate baterako, nahasmendu bipolarra dutenek arazoak dituzte emozio positibo bortitzak gobernatzeko; depresioa dutenek, aldiz, zailtasunak dituzte emozio positiboak jaso edo goratzeko.

- Egonkortasuna: Hobeak ote egonkor edukitzen diren emozio positiboak? Duela gutxiko ikerketen arabera, badirudi aldakortasun handia dagoela emozio positiboetan. Norbaitek aitortuko balu gorabehera handiak dituela bere emozio positiboetan, hori osasun psikologiko ez hain onarekin lotuko litzateke.

- Ahalegintzea: Emozio positiboen atzetik ibiltzeak ongizatea gutxitzea ekar dezake. Zorionaren bila ibiltzeak emaitza moldakaitzak izan ditzake, desengainurako prestatzen duenez.

\section{Ondorioak}

Izenburuan adierazita dagoen bezala, emozio positiboen alde argien eta alde ilunen berri ematea zen lan honen helburua. Horretarako, aurrena emo- 
zio positiboei aitortzen zaizkien ezaugarriak aztertzen saiatu naiz, baita horiei psikologiaren historian egokitu zaien lekua ere. Emozio positiboen alde argi eta ilunak direla eta, harritzekoa da, eta poztekoa ere bai, nola hasierako euforiak bide eman dion azken urteotan alde negatiboen ikerketari. Poztekoa, zeren zorionaren atzetik baitabil jende asko azken aldi honetan, beren bizitzako helburua honela adierazten dutenak: «zoriontsu nahi dut izan, eta kito». Zoriona, ordea, Jose Antonio Marinak (2012) ohartarazten digunez, ez da bila ibil gaitezkeen egoera bat, egiten dugunari lagun egiten dion zerbait baizik. «Gogobetetzea ez dakar jolastu/jokatu izanak, baizik jolasten/jokatzen aritzeak» (2012: 13) ${ }^{40}$. Jende gehienak uste du emozio positiboa ona dela berez. Uste hori zalantzan jartzen dute hasieratik beretik Positive emotion: Integrating the light sides and dark sides liburuaren argitaratzaileek eta emozio positiboen onurak eta kalteak arretaz aztertu dituzten lanez osatu dute liburua. Hemen ere, emozio positiboen bi alderdi horiek jarri nahi izan ditut agerian. Lortu dudan ala ez, hori irakurleak esango du.

\section{Erreferentzia bibliografikoak}

Ahrens, Anthony H. \& Forbes, Courtney N. (2014), «Gratitude». In M.M. Tugade, M.N. Shiota \& L. D. Kirby (arg.), The Handbook of Positive Emotions. New York, NY: Guilford Press, 342-361.

Armentia, Christina N., Fritz, Megan M. \& Sonja Lyubomirsky (2017), «Functions of positive emotions: Gratitude as a motivator of self-improvement and positive change». Emotion Review 9 (3): 183-190. (2018-05-28an jaitsia). DOI: $10.1177 / 1754073916669596$ journals.sagepub.com/home/er

BARRETT, Lisa F. (2006), «Valence is a basic building block of emotional life». Journal of Research in Personality 40: 35-55.

BRADBURN, Norman M. (2016), «Norman M. Bradburn: A pioneer in social indicators and quality of life research». Applied Research Quality Life 11: 325-327.

Campos, Belinda \& Keltner, Dacher (2014), «Shared and differentiating features of the positive emotion domain». In J. Gruber \& J.T. Moskowitz (arg.), Positive emotion: Integrating the light sides and dark sides. New York, NY: Oxford University Press, 52-71.

Carver, Charles S., Scheier, Michael F. \& Johnson, Sheri L. (2014), «Origins and functions of positive affect». In J. Gruber \& J.T. Moskowitz (arg.), Positive emotion: Integrating the light sides and dark sides. New York, NY: Oxford University Press, 34-51.

Condon, Paul, Wilson-Mendenhall, Christine \& BarretT, Lisa F. (2014), «The psychological construction of positive emotion as a window into well-being». In J. Gruber \& J.T. Moskowitz (arg.), Positive emotion: Integrating the light sides and dark sides. New York, NY: Oxford University Press, 11-33.

DAmasio, Antonio (2018), El extraño orden de las cosas. Bartzelona: Planeta.

40 «No es haber jugado lo que nos proporciona satisfacción, sino estar jugando.» (2012: 13) 
Danner, Deborah D., Snowdon, David A. \& Friesen, Wallace V. (2001), «Positive emotions in early life and longevity: findings from the Nun Study». Journal of Personality and Social Psychology 80 (5): 804-813.

Etxebarria, Itziar, Conejero, Susana \& Pascual, Aitziber (2011), «Harrotasuna, aurrera egiten laguntzen digun adiskidea (bere berezitasunekin ...)». In K. Korta \& J.M. Larrazabal (arg.), Gogoz, hitzez eta egitez: Pello Huiziri eskainitako lanak. Bilbo: EHUko Argitalpen Zerbitzua, 149-170.

EusKALTZAINDIA (2012). Euskaltzaindiaren hiztegia. Bilbo: Elkarlanean S. L.

FERNÁNDEZ-ABASCAL, Enrique (2015), Disfrutar de las emociones positivas. Madril: Grupo 5.

ForD, Brett Q. \& MAUss, Iris B. (2014), «The paradoxical effects of pursuing positive emotion». In J. Gruber \& J.T. Moskowitz (arg.), Positive emotion: Integrating the light sides and dark sides. New York, NY: Oxford University Press, 363-381.

ForGas, Joseph P. (2014), «On the downside of feeling good». In J. Gruber \& J.T. Moskowitz (arg.), Positive emotion: Integrating the light sides and dark sides. New York, NY: Oxford University Press, 302-322.

Forgas, Joseph P., Goldenberg, Liz \& UnKelbaCh, Christian (2009), «Can bad weather improve your memory? An unobstrusive field study of natural mood effects on real-life memory». Journal of Experimental Social Psychology 70: 28-40.

FREDRICKSON, Barbara L. (1998), «What good are positive emotions?» Review of General Psychology 2 (3): 300-319.

Fredrickson, Barbara L. \& LeVEnson, Robert W. (1998). «Positive emotions speed recovery from the cardiovascular sequelae of negative emotions». Cognition and Emotion 12 (2): 191-220.

FREDRICKSON, Barbara L. (2001), «The role of positive emotions in positive psychology». American Psychologist 56 (3): 218-226.

FREDRICKSON, Barbara. L. (2003), «The value of positive emotions». American Scientist, 91: 330-335.

FredricKSON, Barbara L. \& CoHN, Michael A. (2008), «Positive emotions». In M. Lewis, J.M. Haviland-Jones \& L. Feldman Barrett (arg.), Handbook of emotions. New York, NY: The Guilford Press, 777-796.

FREDRICKSON, Barbara L. (2013), «Positive emotions Broaden and Build». In P. Devine \& A. Plant (arg.), Advances in Experimental Social Psychology, vol. 47. Burlington: Academic Press, 1-53.

Gruber, June, Devlin, Hillary C. \& Moskowitz, Judith T. (2014), «Seeing it all». In J. Gruber \& J.T. Moskowitz (arg.), Positive emotion: Integrating the light sides and dark sides. New York, NY: Oxford University Press, 3-8.

Gruber, June \& Moskowitz, Judith T. (arg.) (2014), Positive Emotion: Integrating the light sides and dark sides. New York, NY: Oxford University Press.

Gruber, June \& PurCell, John (2015), «Positive emotion disturbance». In R. Scott \& S. Kosslin (arg.), Emerging Trends in the Social and Behavioral Sciences. http://www. gruberpeplab.com/pdf/2015_Gruber.Purcell_ThemesPositiveEmotionDisurbance. pdf (2018/02/07an jaitsia).

Huizi, Pello (2011), «Epilogoa». In K. Korta \& J.M. Larrazabal (arg.), Gogoz, hitzez eta egitez: Pello Huiziri eskainitako lanak. Bilbo: EHUko Argitalpen Zerbitzua.

Huizi, Pello (2016), «Emozioen eragina erabakiak hartzean». Gogoa 14: 153-178.

IsEN, Alice M. (1970), «Success, failure, attention, and reaction to others: The warm glow of success». Journal of Personality and Social Psychology 17: 107-112. 
IsEN, Alice M. (1987), «Positive affect, cognitive processes, and social behavior». Advances in Experimental Social Psychology 20: 203-253.

IsEN, Alice M. \& Levin, Paula F. (1972), «The effect of feeling good on helping: Cookies and kindness». Journal of Personality and Social Psychology 21: 384-388.

Isen, Alice M., Johnson, Mitzi M.S., MerTz, Elizabeth \& Robinson, Gregory F. (1985), «The influence of positive affect on the unusualness of word associations». Journal of Personality and Social Psychology 48: 1413-1426.

Isen, Alice M., Nygren, Thomas E. \& Asby, F. Gregory (1988), «The influence of positive affect on the perceived utility of gains and losses». Journal of Personality and Social Psychology 55: 71-171.

Keltner, Dacher \& HAidT, Jonathan (1999), «Social functions of emotions at four levels of analysis». Cognition and Emotion 13: 505-521.

KeltNer, Dacher \& KRING, Ana M. (1998), «Emotion, social function, and psychopatology». Review of General Psychology 2: 320-342.

Kok, Bethany E., Coffey, Kimberly A., Cohn, Michael A., Catalino, Lahnna I., Vacharkulksemsuk, Tanya, Algoe, Sara B., Brantley, Mary \& Fredrickson, Barbara L. (2013), «How positive emotions build physical health: Perceived positive social connections account for the upward spiral between positive emotions and vagal tone». Psychological Science 24 (7): 1123-1132. DOI: 10.1177/0956797612470827 pss.sagepub.com

Konstan, David (2000), «La pitié comme émotion chez Aristote». Revue des Études Grecques 113, Juillet-Décembre: 616-630. DOI: 10.3406/reg.2000.4429

Korta, Kepa \& Larrazabal, Jesus Mari (arg.) (2011), Gogoz, hitzez eta egitez: Pello Huiziri eskainitako lanak. Bilbo: EHUko Argitalpen Zerbitzua.

Leighton, Stephen R. (1996), «Aristotle and the emotions». In A. O. Rorty (arg.), Aristotle's Rhetoric. Berkeley, Kalifornia: University of California Press, 206-237.

MARINA, José Antonio (2012), La inteligencia ejecutiva. Bartzelona: Ariel.

MasLow, Abraham (1970), Motivation and Personality. 3. ed. New York: Harper \& Row.

Mora, Francisco (2017), Neuroeducación. Madril: Alianza Editorial.

MorgADO, Ignacio (2010), Emociones e inteligencia social. Bartzelona: Ariel.

Moskowitz, Judith T., Clark, Margaret S., OnG, Anthony D. \& Gruber, June (2014), «The role of positive affect on thinking and decision-making: A tribute to Alice Isen». In J. Gruber \& J.T. Moskowitz (arg.), Positive emotion: Integrating the light sides and dark sides. New York, NY: Oxford University Press, 72-77.

Moskowitz, Judith T. \& SAslow, Laura R. (2014), «Health and psychology». In M.M. Tugade, M.N. Shiota \& L.D. Kirby (arg.), The Handbook of Positive Emotions. New York, NY: Guilford Press, 413-431.

Oatley, Keith \& Johnson-Laird, Philip N. (2013), «Cognitive approaches to emotions». Trends in Cognitive Sciences, xx: 1-7. DOI: 10.1016/j.tics.2013.12.004

Ong, Anthony D., BonanNo, George A. \& Bergeman, Cindy S. (2014), «Positive emotions in the aftermath of loss». In J. Gruber \& J.T. Moskowitz (arg.), Positive emotion: Integrating the light sides and dark sides. New York, NY: Oxford University Press, 267-278.

Ostir, Glenn V., Markides, Kyriakos S., Black, Sandra A. \& Goodwin, James S. (2000), «Emotional well-being predicts subsequent functional independence and survival». Journal of the American Geriatrics Society 48 (5): 473-478.

Pressman, Sarah D. \& Bowlin, Stephanie L. (2014), «Positive affect». In J. Gruber \& J.T. Moskowitz (arg.), Positive emotion: Integrating the light sides and dark sides. New York, NY: Oxford University Press, 183-205. 
Pressman, Sarah D. \& Cohen, Sheldon (2012), «Positive emotion word use and longevity in famous deceased psychologists». Health Psychology 31 (3) : 297-305.

Reeves, Elizabeth J., LeibenLuft, Ellen \& Gruber, June (2014), «Positive emotion disturbance in bipolar disorder across the lifespan». In J. Gruber \& J. T. Moskowitz (arg.), Positive emotion: Integrating the light sides and dark sides. New York, NY: Oxford University Press, 434-450.

RICARD, Matthieu (2014), La psychologie positive ne consiste a «positiver». http://www. matthieuricard.org/blog/posts/la-psychologie-positive-ne-consiste-pas-a-positiver (2018-04-20an jaitsia).

SAMSON, Andrea C. \& Gross, James J. (2014), «The dark and light sides of humor». In J. Gruber \& J.T. Moskowitz (arg.), Positive emotion: Integrating the light sides and dark sides. New York, NY: Oxford University Press, 169-182.

Sauter, Disa A., McDonald, Nicole M., Gangi, Devon N. \& Messinger, Daniel S. (2014), «Nonverbal expressions of positive emotions». In M.M. Tugade, M.N. Shiota \& L.D. Kirby (arg.), The Handbook of Positive Emotions. New York, NY : Guilford Press, 179-198.

Seligman, Martin (2002), Authentic happiness. New York: Free Press. (Gaztelaniazko bertsioa, La auténtica felicidad. Bartzelona: Vergara, 2003.)

Shiota, Michelle N. (2014), «The evolutionary perspective in positive emotion research». In M.M. Tugade, M.N. Shiota \& L.D. Kirby (arg.), The Handbook of Positive Emotions. New York, NY: Guilford Press, 44-59.

Simón, Vicente (2015), El corazón del Mindfulness: la conciencia amable. Bartzelona: Sello Editorial.

SkInNeR, Burrhus F. (1962), Walden two. New York, NY: Macmillan Paperbacks.

Smith, Craig A., Tong, Eddie M.W. \& Ellsworth, Phoebe C. (2014), «The differentiation of positive emotional experience as viewed through the lens of Appraisal Theory». In M.M. Tugade, M.N. Shiota \& Leslie D. Kirby (arg.), The Handbook of Positive Emotions. New York, NY: Guilford Press, 11-27.

Stellar, Jennifer E. \& Keltner, Dacher (2014), «Compassion». In M.M. Tugade, M.N. Shiota \& L.D. Kirby (arg.), The Handbook of Positive Emotions. New York, NY: Guilford Press, 329-341.

Tracy, Jessica L., Weidman, Aaron C., Cheng, Joey T. \& Martens, Jason P. (2014), «Pride». In M.M. Tugade, M.N. Shiota \& L.D. Kirby (arg.), The Handbook of Positive Emotions. New York, NY: Guilford Press, 294-310.

Tugade, Michele M., Shiota, Michelle N. \& Kirby, Leslie D. (arg.) (2014), The Handbook of Positive Emotions. New York, NY: Guilford Press.

Turowsky, Tabitha K., Man, Vincent Y. \& Cunningham, William A. (2014), «Positive emotion and the brain». In J. Gruber \& J.T. Moskowitz (arg.), Positive emotion: Integrating the light sides and dark sides. New York, NY: Oxford University Press, 95115.

Vecina Jiménez, M. Luisa (2006), «Emociones positivas». Papeles del Psicólogo 27 (1): 9-17.

Williams, Lisa A. \& DeSteno, David (2014), «How positive social emotions motivate actions for the future self». In J. Gruber \& J.T. Moskowitz (arg.), Positive emotion: Integrating the light sides and dark sides. New York, NY: Oxford University Press, 206-224.

Yee, Claire I., Gonzaga, Gian C. \& Gable, Shelly L. (2014), «Positive emotions in close relationships». In M.M. Tugade, M.N. Shiota \& L.D. Kirby (arg.), The Handbook of Positive Emotions. New York, NY: Guilford Press, 215-228. 